\title{
Persepsi Akuntan dan Ulama' terhadap Problematika Etika Profesi Akuntan Publik Perspektif Islam
}

\author{
Risqifani $^{*}$, Suwarno ${ }^{2 \dagger}$ \\ ${ }^{1}$ Universitas Muhammadiyah Gresik
}

\begin{abstract}
This study aims to identify the factors and the impact of the many cases of violations of the professional ethics of public accountants through the perceptions of accountants and Ulama'. The study used qualitative methods with a case study approach. The data collection technique was done by in-depth interviews with informants who meet the criteria in this study. The results showed that economic factors and personal interest factors were the main factors that could make public accountants violate ethics in their profession. In an Islamic perspective, violations of the professional ethics of public accountants are not based on ethics in Islam, because they contain elements of dishonesty of public accountants in terms of presenting opinions on financial statements, As explained in the Al-Baqarah verse 79, that it will be disastrous for people who do not write according to the truth for the sake of seeking profit. The existence of faith in every job becomes the main thing as the basis for public accountants to carry out their profession. With strong faith, the intention to violate the professional ethics of public accountants can be minimized.
\end{abstract}

Keywords: Violations, Ethics, Public Accountants, Islamic Perspective.

Tipe artikel: kualitatif-case study

\section{Pendahuluan}

\subsection{Latar Belakang Masalah}

Sejak terjadinya skandal moral hazard yang dilakukan oleh Enron pada akhir tahun 2001 yang juga melibatkan salah satu KAP terbesar di dunia yang tergabung dalam The Big Five yaitu KAP Arthur Andersen (AA), etika profesi menjadi kajian yang menarik dalam dunia akuntansi. Kekeliruan dalam praktek akuntansi oleh Worldcom di mana terjadi manipulasi laporan keuangan oleh manajemen puncak dan juga CEO WorldCom, merupakan salah satu penyebab dari penggelembungan arus kas tersebut. Tidak hanya di luar negeri, di Indonesia juga tidak luput dari adanya kasus pelanggaran etika profesi oleh Akuntan Publik. Di mana pada tahun 2006 terdapat kasus yang menimpa Akuntan Publik Justinus Aditya Sidharta (JAS), yang di indikasi melakukan kesalahan dalam mengaudit laporan keuangan PT

\footnotetext{
${ }^{*}$ Penulis yang sesuai:

E-mail: Risqifani@umg.ac.id

Afiliasi: Universitas Muhammadiyah Gresik

${ }^{\dagger}$ Penulis yang sesuai:

E-mail: suwarno@umg.ac.id

Afiliasi: Universitas Muhammadiyah Gresik
} 
Great River Internasional, Tbk. Kasus tersebut terjadi setelah adanya temuan auditor investigasi dari BAPEPAM yaitu Amir Abadi Jusuf dan Mawar, yang menemukan indikasi penggelembungan account penjualan, piutang dan Asset. Berdasarkan investigasi tersebut, akhirnya BAPEPAM menyatakan bahwa akuntan publik yang memeriksa laporan keuangan PT Great River Internasional, Tbk ikut menjadi tersangka. Oleh karenanya, terhitung sejak tanggal 28 November 2006 Menteri keuangan RI membekukan izin akuntan publik Justinus Aditya Sidharta (JAS) selama dua tahun karena terbukti melakukan pelanggaran terhadap Standar Profesi Akuntan Publik (Tjun Tjun, 2012).

Dengan adanya beberapa kasus seperti diatas yaitu Akuntan Publik yang melakukan pelanggaran dalam profesinya, beberapa ahli mengatakan bahwa hal tersebut didasari karena kegagalan dalam menerapkan etika profesi. Godaan yang besar dalam profesi Akuntan Publik merupakan salah satu penyebab kegagalan ini. Godaan tersebut datang dari dua kepentingan, yaitu kepentingan korporasi dan kepentingan pribadi. Di satu sisi, pekerjaan Akuntan Publik mempunyai akibat terhadap eksistensi perusahaan atau lembaga di mata publik. Di lain sisi, Akuntan Publik berhadapan dengan berbagai ancaman yang muncul dari diri sendiri seperti ancaman kepentingan pribadi maupun ancaman dari luar seperti intimidasi dan kepentingan keluarga. ((IFAC, Section 100) dalam (Sitohang, 2016)). Hal tersebutlah yang dimaksud dengan dilema etika. Dilema etika merupakan suatu keadaan dimana seseorang harus menentukan keputusan yang mencangkup sikap yang patut (J.Elder, 2013).

Etika telah banyak dibahas pada Al-Qur'an dan Hadist. Dalam (Muzakkir, 2016), terdapat tiga terma kunci utama yang merupakan pandangan dunia Al-Qur'an tentang etika, diantaranya yaitu Islam, iman dan taqwa yang jika direnungkan akan menghasilkan arti yang sama. Istilah iman lahir dari kata "amanah" yang artinya keamanan, damai, dan bebas dari bahaya. Sedangkan Islam sendiri timbul dari kata "salam" yang artinya aman dan integral, terlindungi dari disintegrasi dan kehancuran. Dan taqwa yang sangat mendasar bagi Al-Qur'an disamping kedua istilah diatas, yang memiliki akar kata "waqayah" juga berarti melindungi dari bahaya, menjaga kemusnahan, kesia-siaan, atau disintegrasi. Maka, dapat disimpulkan pembahasan tentang etika yang tertera didalam Al-Qur'an, memiliki makna yang luas karena terkait dengan nilai yang ada didalam kehidupan seluruh manusia agar mencapai kemaslahatan didunia dan akhirat. Islam juga tentunya memandang pelanggaran dalam etika profesi yang dilakukan oleh professional termasuk akuntan publik, sebagai hal yang sangat tidak dianjurkan karena hal tersebut telah menyalahi prinsip-prinsip kebenaran dalam Islam.

Penelitian mengenai etika profesi akuntan pernah dilakukan, misalnya pada penelitian (Koerniawan, 2013) yang menjelaskan bahwa "Penelitian yang dilakukan oleh Volker (1984), Bebeau, et al (1985) mengatakan bahwa para Akuntan Profesional cenderung mengabaikan persoalan moral bilamana menemukan masalah yang bersifat teknis. Kemudian, Cushing (1999) yang menawarkan sebuah kerangka kerja berdasarkan Game Theory untuk melakukan pengujian pendekatan standar etika pada profesi akuntan publik. Selain itu, ada juga penelitian yang dilakukan oleh Ludigdo (1999) menghasilkan rumusan bahwa pelanggaran etika seharusnya tidak terjadi apabila akuntan memiliki pengetahuan, pemahaman, serta kemauan dalam menerapkan nilai-nilai moral dan etika secara memadai dalam pelaksanaan pekerjaan profesionalnya. Sedangkan, hasil Penelitian Payamta (2002) menyatakan bahwa berdasarkan Pedoman Etika IFAC, maka syarat-syarat etika suatu organisasi akuntan, sebaiknya didasarkan pada prinsip-prinsip dasar yang mengatur tindakan atau perilaku seorang akuntan dalam melaksanakan tugas profesionalnya. Dan yang menarik adalah pendapat dari Sudibyo (1995) dalam Khomsiyah dan Indriantoro (1998) yang menyatakan bahwa Dunia Pendidikan Akuntansi memiliki pengaruh yang besar terhadap perilaku etika dari Auditor. Pendapat dari Sudibyo seolah memberikan informasi bagi kita, bahwa ketika kita berbicara etika profesi Akuntan Publik maka hal tersebut juga memiliki kaitan dengan implementasi etika profesi Akuntan Pendidik". Namun, sebagian besar dari penelitian tersebut hanya mencoba untuk mengungkapkan faktor penyebab akuntan melakukan pelanggaran etika profesi. Oleh karenanya, melalui pendekatan kualitatif, penulis berkeinginan untuk menggali informasi lebih lanjut bagaimana persepsi, sikap, maupun tanggapan akuntan publik, dan ulama' mengenai tindakan pelanggaran etika profesi akuntan publik yang menjadi problematika di era kompetitif seperti sekarang ini, dengan mengaitkannya pada etika dalam Islam.

\subsection{Rumusan Masalah}

Dari uraian latar belakang diatas maka rumusan masalah dalam penelitian ini adalah bagaimana persepsi akuntan dan ulama' terhadap problematika etika profesi akuntan publik menurut perspektif Islam? 


\section{Tinjuan Pustaka}

\subsection{Persepsi}

Dalam artian secara umum persepsi merupakan pandangan atau pengamatan seseorang terhadap suatu objek, peristiwa atau kejadian. Dari persepsi tersebut menghasilkan pemikiran yang berbeda antara satu individu dengan individu lain. (Danarjati \& Ekawati, 2013) mendefinisikan persepsi merupakan proses bagaimana seseorang menyeleksi, mengatur dan menginterpretasikan informasi dan pengalaman yang didapat kemudian menafsirkan untuk menciptakan keseluruhan gambaran yang berarti.

Menurut (Aw, 2010), "Persepsi merupakan proses internal yang dilalui individu dalam menyeleksi, dan mengatur stimuli yang datang dari luar. Stimuli itu ditangkap oleh indera, secara spontan pikiran dan perasaan kita akan memberi makna atas stimuli tersebut. Secara sederhana persepsi dapat dikatakan sebagai proses individu dalam memahami kontak atau hubungan dengan dunia sekelilingnya".

Dari beberapa pengertian persepsi diatas maka dapat dikatakan bahwa persepsi merupakan pandangan seseorang terhadap suatu objek, peristiwa serta kejadian dalam pusat perhatiannya. Dalam penelitian ini teori persepsi digunakan untuk mengetahui pandangan informan mengenai tindakan pelanggaran etika profesi akuntan publik jika ditinjau dari etika dalam perspektif Islam.

\subsection{Pengertian Etika}

Menurut Kamus Besar Bahasa Indonesia dalam (Tanyid, 2014), kata "etika" berarti perilaku mengenai apa yang baik dan buruk, serta mengenai hak dan kewajiban moral. Sekumpulan asas atau nilai tentang akhlak dan nilai mengenai apa yang benar dan salah yang dapat menjadi contoh oleh masyarakat.

Dari asal usul kata, etika berasal dari bahasa Yunani Kuno yaitu "ethos" yang memiliki arti, yaitu adat kebiasaan, cara berfikir, akhlak, sikap, watak, cara bertindak (Sitohang, 2016). Kata etika setara dengan perkataan moral yang berasal dari istilah latin yaitu "Mos" dengan bentuk jamak "Moses" yang berarti adat atau cara hidup dengan melakukan hal yang baik dan tidak melakukan tindakan yang buruk atau tidak sesuai norma dalam masyarakat. Etika merupakan dasar dari cara berprilaku yang baik dan benar sesuai dengan perspektif agama, budaya serta susila.

Ronald F. Duska dan Brenda Shay Duska (2003) dalam (Sitohang, 2016) mendefinisikan etika sebagai teori tentang nilai moral atau prinsip perilaku apa yang baik dan yang buruk, untuk mengatur perilaku individu atau kelompok dalam kehidupan. (Sosipater, 2012) meringkas arti etika dalam dua hal yaitu " (1) penilaian apa yang benar dan apa yang salah dalam perilaku manusia, serta (2) sebuah cabang ilmu, tepatnya cabang filsafat, yakni pemikiran kefilsafatan tentang moralitas, problem moral, dan pertimbangan moral.

Ricky W.Griffin dan Ronald J.Ebert (2006) dalam (Arifiyani, 2012) mendefinisikan perilaku etis merupakan perilaku atau tindakan yang baik dan benar sesuai dengan norma sosial yang dapat diterima masyarakat umum. Perilaku etis ini dapat menentukan kualitas individu yang juga dipengaruhi oleh faktor eksternal dan kemudian menjadi suatu prinsip yang digunakan dalam bingkai perilaku individu tersebut.

\subsection{Etika Menurut Perspektif Agama Islam}

Islam memberikan etika dalam semua aspek termasuk bisnis dan profesi dengan berlandaskan pada keteladanan Rasulullah Muhammad SAW, baik sebelum maupun setelah diangkat menjadi Rasul. (Sirajudin, 2013) 
Pegangan dan landasan utama dalam etika Islam adalah Al-Qurean dan As-Sunnah karena pandangan umum masyarakat Islam tentang berbagai perilaku benar dalam melaksanakan kewajiban agama, pemahaman yang benar tentang keagamaan tidak bisa dipisahkan dari berbagai unsur pokok dalam kehidupan moral. Dalam (Narjono, 2013), sistem etika Islam (Islam ethical system) merupakan suatu sistem yang unik, karena sistem etika Islam tidak memisahkan sistem etik dengan agama, Islam menekankan pada keseimbangan kehidupan dunia dan akhirat. Jadi, terdapat suatu tuntutan untuk melakukan tindakan yang proporsional dan pengawasan pada tindakan tersebut. Sehingga akan menimbulkan keyakinan bahwa tindakan yang dilakukan didunia akan mendapatkan implikasi di kehidupan akhirat.

Menurut Beekun (1997) dalam (Narjono, 2013) terdapat beberapa parameter kunci untuk sistem etika Islam, yaitu :

1. Perilaku etis bergatung pada niat baik masing-masing individu.

2. Niat yang baik harus diikuti oleh perbuatan yang baik. Niat baik tidak dapat mengubah perbuatan haram menjadi halal.

3. Islam memberikan kebebasan individu untuk mempercayai sesuatu atau berbuat sesuatu, selama tidak mengorbakan nilai tanggungjawab dan keadilan.

4. Harus terdapat kepercayaan bahwa Allah memberikan kepada individu pembebasan (freesdom) yang komplit, dari sesuatu atau siapa pun selain Allah.

5. Keputusan mengenai keuntungan mayoritas atau minoritas tidak diperlukan. Sebab etika bukanlah permainan angka.

6. Islam menggunakan sistem pendekatan terbuka kepada etika, tidak tertutup atau selforiented system. Tidak ada rasa egoisme dalam Islam.

Pada dasarnya, Islam diturunkan sebagai kode perilaku moral dan etika bagi kehidupan manusia. Seperti yang telah dikemukakan dalam hadist dari Abu Hurairah Radhiyallahu'Anhu, Rasulullah Shallallahu „Alaihi Wasallam bersabda:

Artinya: "Sesungguhnya aku diutus hanya untuk menyempurnakan keshalihan akhlak." (HR. Al-Baihaqi).

Seperti dalam hadist tersebut, istilah yang paling dekat dengan definisi etika dalam Islam adalah akhlak. Islam menganggap bahwa etika (akhlak) merupakan cerminan kepercayaan Islam (iman). Konsep etika dalam Islam bersifat mutlak dan abadi, tidak bersifat utilitarian dan relative. Jadi, Islam menjadi sumber nilai dan etika dalam segala aspek kehidupan manusia secara menyeluruh, termasuk dalam dunia bisnis. Pramono (2004) dalam (Narjono, 2013), memaparkan empat aksioma etika ekonomi yaitu tauhid, keseimbangan (keadilan), kebebasan dan pertanggung jawaban.

\section{Tauhid}

Konsep Tauhid yang dalam pengertian absolut dan hanya berhubungan dengan Tuhan mencerminkan sistem etika Islam, yang meliputi kehidupan manusia secara menyeluruh. Konsep ini juga menciptakan prinsip gabungan yang kuat, dalam hal keberadaan (eksistensi) manusia, karena seluruh manusia dipersatukan dalam ketaatan pada-Nya. Hal tersebut terlihat dalam (QS. Al-An“eam 6: 162) yang artinya "Katakanlah, sesungguhnya shalatku, ibadatku, hidupku, dan matiku hanya untuk Allah,

Tuhan Semesta Alam".

2. Kesetimbangan

Lingkup kehidupan dalam kebulatan homogen berada dalam perspektif Islam. Agar menghasilkan tatanan sosial yang paling baik, maka analisanya yang beragam harus disetimbangkan: "Sesungguhnya Kami menciptakan segala sesuatu menurut ukuran" (QS. Al-Qamar 54 : 49). Eksistensi manusia itu sendiri membawa semua sifat dasar 
pemberi hidup ke dalam kesetimbangan yang tak berbeda sehingga setiap pengerusakan merupakan kejahatan yang nyata yang akan berdampak pada penghapusan kehidupan itu sendiri.

3. Kebebasan

Kebebasan yang diberikan oleh Tuhan kepada manusia harus dilindungi melalui penciptaan perlindungan institusi atau norma yang mencegah pencemaran yang mungkin dilakukan oleh ketidakwajaran otoriterisme. Jadi tidak diperlukan magna carta untuk memberi manusia kebebasan yang merupakan pemberian dari Tuhan. Sebab, apabila kebebasan manusia adalah pemberian Tuhan dan setiap individu bertindak sesuai dengan etika kebebasan itu, maka unsur paksaan yang muncul karena penyesuaian antara kepentingan pribadi dan sosial haruslah berkurang. Agar dapat memenuhi kondisi masyarakat yang islami, maka konflik kepentingan pribadi dan sosial seperti itu harus ditiadakan.

4. Pertanggung jawaban

Aksioma pertanggung jawaban, secara logis berhubungan dengan kehendak bebas. Dalam Islam, Allah memberikan norma mengenai apa yang bebas dilakukan oleh manusia pada semua tindakan yang diperbuat dengan menyertakan rasa bertanggungjawab: "Barangsiapa yang memberikan syafa'at yang baik, niscaya ia akan memperoleh bahagian (pahala) dari padanya. Dan barangsiapa memberi syafa'at yang buruk, niscaya ia akan memikul bahagian (dosa) dari padanya. Allah Maha Kuasa atas segala sesuatu" (QS. An-Nisa 4:85). Selanjutnya, Islam tidak membolehkan pemujaan kepada individualisme yang tak terkendalikan dan tak beretika. Bahkan logika murni harus meyakinkan kita bahwa kebebasan yang tak terbatas adalah sesuatu yang dibuat-buat. Kebebasan yang tak terbatas merupakan pertanggungjawaban yang tak terbatas. Sebab setiap makhluk akan menanggung atas apa yang dia tamankan. Seperti yang tercermin dalam (QS. Al-Muddatsir 74:38), "Tiap-tiap diri bertanggugjawab atas apa yang telah diperbuatnya".

Menurut (Pulungan, 2014), implementasi dari bekerja perlu dilandasi dan diikat oleh ahlak atau etika atau dalam kata lain landasan etika profesi. Terdapat empat cerminan dari etika profesi, yaitu amanah, tabligh, fathanah, dan istiqamah.

1. Amanah

Amanah yang berarti tanggung jawab. Dalam segala hal, amanah digambarkan dengan bentuk keterbukaan, pelayanan yang optimal, kejujuran dan ihsan (berbuat yang terbaik). Ketika melaksanakan setiap tugas dan kewajiban pada pekerjaannya, seorang Akuntan Publik haruslah mempunyai sifat amanah, agar setiap apa yang dikerjakan dalam pekerjaannya dapat dipertanggung jawabkan pada pengguna jasa mereka (khususnya pengguna laporan keuangan) dan tentunya kepada Tuhannya, yang akan berimplikasi pada tidak adanya unsur pelanggaran pada etika profesi.

2. Tabligh

Tabligh berarti menyampaikan kebenaran atau dengan kata lain mengajak sekaligus memberikan contoh kepada pihak lain untuk melaksanakan ketentuan-ketentuan ajaran Islam untuk diterapkan dalam kehidupan sehari-hari. Ketika tabligh disampaikan dengan sabar, hikmah, argumentatif, dan persuasive akan menumbuhkan hubungan kemanusiaan yang semakin solid dan kuat. Akuntan Publik juga harus memiliki sifat tabligh dalam profesinya, yang berarti Akuntan Publik harus menyampaikan kebenaran pada laporan keuangan yang telah diauditnya pada pengguna laporan keuangan tanpa melibatkan unsur kecurangan atau pelanggaran etika profesi.

3. Fathanah

Fathanah yang berarti cerdas atau pandai atau dengan kata lain setiap orang dalam melaksanakan profesinya haruslah memahami dan menghayati secara mendalam 
segala yang menjadi tugas dan kewajibannya. Fathanah akan menumbuhkan kreatifitas dan kemampuan melakukan berbagai macam inovasi yang bermanfaat. Sifat kreatif dan inovatif hanya mungkin dimiliki manakala seseorang selalu berusaha menambah berbagai macam ilmu pengetahuan, peraturan dan informasi, baik yang berhubungan dengan pekerjaannya maupun perusahaan secara umum. Tentunya, Akuntan Publik dalam melaksanakan profesinya haruslah memahami dan menghayati secara mendalam segala yang menjadi tugas dan kewajibannya, termasuk pertanggung jawaban pada laporan keuangan yang diauditnya untuk disampaikan ke pengguna laporan keuangan secara transparan.

4. Istiqomah

Istiqomah yaitu konsisten. Konsisten dalam kebaikan ditampilkan dalam keteguhan dan kesabaran serta keuletan sehingga menghasilkan sesuatu yang optimal. Istiqomah merupakan hasil dari suatu proses yang dilakukan secara terus menerus. Misalnya interaksi yang kuat dengan Allah dalam bentuk shalat, zikir, membaca Al-Qur ${ }^{\text {re an dan }}$ lain-lain. Proses itu akan berdampak pada suatu sistem yang memungkinkan kebaikan, kejujuran, keterbukaan, teraplikasikan dengan baik. Sebaliknya, keburukan dan ketidakjujuran akan tereduksi dan ternafikan secara nyata. Orang yang istiqomah dalam kebaikan akan mendapatkan ketenangan dan sekaligus mendapatkan solusi dan jalan keluar dari segala persoalan yang menimpanya. Sifat istiqomah perlu diterapkan oleh Akuntan Publik dalam profesinya, yaitu melakukan perbuatan baik secara konsisten dengan cara mengaudit laporan keuangan secara benar dan menyampaikannya secara transparan kepada pengguna laporan keuangan tanpa sedikitpun melakukan kecurangan yang menyebabkan pelanggaran etika profesi.

Akuntan Publik harusnya memiliki keempat etika bisnis tersebut. Dalam menjalankan profesinya, akuntan publik harus memilki sikap tidak melupakan akhirat, karena dengan adanya sikap tidak melupakan akhirat tentunya motivasi dalam bekerja karena Allah akan dianggap sebagai jihad sehingga tugas yang diberikan akan dilakukan dengan rasa jujur, murah hati, dan bisa dipertanggungjawabkan (amanah) sehingga bermanfaat bagi umat dan tentunya akan mendorong Akuntan Publik untuk tidak melakukan pelanggaran etika profesi (kecurangan) seperti manipulasi laporan keuangan yang telah diaudit, yang akan berdampak pada kerugian pengguna laporan keuangan yaitu pemegang saham.

Selain etika dalam bisnis yang harus dimiliki, akuntan publik juga seharusnya memiliki rasa religiusitas pada motivasi kerja dan etika profesinya. Karena, kualitas akuntan publik dipengaruhi oleh tingkat religiusitas pada dirinya. Ketika rasa religiustias yang tinggi dimiliki oleh akuntan publik maka akan menciptakan pola fikir yang positif dan selalu bersemangat sehingga tidak malu untuk belajar sesuatu yang baru dan berdampak pada terciptanya tanggung jawab dalam menyelesaikan pekerjaan (termasuk bertanggung jawab pada laporan keuangan yang diauditnya), berperilaku santun dan ramah kepada semua orang, sehingga cenderung menjadi orang menyenangkan dan disukai banyak orang. Menurut (Kusumaningtyas, 2016), nilai religiusitas dapat membuat Akuntan untuk bersikap sesuai etika. Atau dengan kata lain, nilai religiusitas secara tidak langsung dapat menciptakan rasa takut dalam diri Akuntan ketika dia melakukan hal yang melanggar perintah Tuhan atau menjalankan hal yang dilarang dalam Agama.

\section{Metode Penelitian}

\subsection{Pendekatan Penelitian}


Penelitian ini bertujuan untuk mengetahui, memahami serta memaknai pelanggaran etika profesi akuntan publik apabila ditinjau dari perpektif etika dalam Islam. Oleh karenanya, untuk mencapai pemahaman yang mendalam maka digunakan pendekatan kualitatif deskriptif dalam penelitian ini. Penelitian kualitatif disebut juga penelitian interpretive karena data hasil penelitian lebih berkenaan dengan interprestasi terhadap data yang ditemukan dilapangan (Sugiyono, 2015). Oleh karena itu, hal tersebut akan membantu peneliti untuk mengkaji dan memaknai lebih mendalam mengenai problematika etika akuntan publik dalam perpektif Islam melalui persepsi akuntan dan ulama'.

Studi kasus adalah sebuah penyelidikan empiris yang menginvestigasi fenomena kontemporer dalam konteks kehidupan nyata, khususnya ketika batas antara fenomena dan konteks tidak begitu jelas. (Yin, 2011) juga mengatakan bahwa tujuan penelitian studi kasus adalah untuk menjelaskan bagaimana keberadaan dan mengapa kasus tersebut terjadi. Jadi, penelitian studi kasus tidak hanya menjawab pertanyaan penelitian mengenai "apa" (what) obyek penelitian yang diteliti, tetapi lebih menyeluruh dan komprehensif dengan pertanyaan penelitian "bagaimana" (how) dan "mengapa" (why).

\subsection{Subyek Penelitian}

Pada penelitian ini beberapa informan yang dipilih merupakan informan yang memahami tentang etika Akuntan Publik dan Islam. Terdapat dua informan yang dipilih dalam penelitian ini yaitu Akuntan Publik dan Ulama'. Selain karena memahami tentang etika Akuntan Publik dan Islam, sudut pandang atau bagaimana persepsi masing-masing informan dalam menanggapi kasus pelanggaran etika profesi Akuntan Publik dengan dihubungkan pada etika Islam sangat diperlukan karena akan mempengaruhi hasil penelitian.

\subsection{Metode Pengumpulan Data}

Dalam penelitian kualitatif, pengumpulan data dilakukan secara alamiah atau pada kondisi yang tanpa dibuat sebelumnya (natural setting), dan terdapat tiga metode pengumpulan data dalam penelitan kualitatif, yaitu observasi (observation), wawancara mendalam (in depth interview) dan dokumentasi. Sedangkan dalam penelitian ini, peneliti mengumpulkan data dengan menggunakan metode wawancara mendalam. Sebelum melakukan wawancara kepada informan, peneliti membuat rancangan pertanyaan yang berkaitan dengan rumusan masalah penelitian. Untuk mendapatkan jawaban yang lebih lengkap, akurat, dan tanpa terikat maka proses wawancara dilakukan secara tidak terstruktur dan informal.

\subsection{Unit Analisis}

Unit analisis merupakan seluruh sumber informasi dari pengolahan variabel penelitian (Zulganef, 2008). Dalam penelitian ini, peneliti menggunakan unit analisis sikap dari sudut pandang etika dalam Islam. Etika profesi yang harusnya dimiliki dan diterapkan oleh akuntan publik dalam menjalankan tugasnya sebagai pemeriksa laporan keuangan yang akurat dan transparan sehingga berguna dan tidak merugikan pengguna laporan keuangan tersebut. Unit analisis ini ditentukan dari bagaimana persepsi masing-masing informan menanggapi kasus pelanggaran etika profesi Akuntan Publik yang menyebabkan problematika dalam perspektif etika Islam, yang didasarkan dengan beberapa sikap etis yaitu diantaranya kejujuran, obyektifitas, kompetensi, amanah, kemanfaatan dan berdasar pada nilai moral agama, masyarakat dan keadilan.

\subsection{Teknik Analisis Data}


Dalam penelitian kualitatif teknik analisis data dimulai dari pengumpulan data berlangsung dan setelah selesai pengumpulan data pada jangka waktu tertentu. Teknik analisis data dalam penelitian ini mengacu pada ((Sanders (1982) dalam (Sopanah, 2010)), yang menggambarkan siklus analisis data penelitian kualitatif sebagai berikut :

1. Deskripsi fenomena

Dalam tahap awal penelitian dimulai dengan mendiskripsikan fenomena yang berkaitan dengan pelanggaran etika profesi Akuntan Publik. Ditinjau dari hasil penelitian terdahulu yang menyatakan adanya perbedaan persepsi mengenai faktor penyebab Akuntan Publik melakukan pelanggaran etika profesi sehingga menyebabkan problematika. Hal tersebut dibahas oleh peneliti dalam latar belakang penelitian. Oleh karenanya, peneliti akan lebih mudah merumuskan masalah dengan melihat fenomena tersebut, yang nantinya menjadi bahasan penelitian.

2. Identifikasi tema - tema

Tahapan kedua yaitu identifikasi tema-tema. Tahapan ini merupakan tahapan yang paling dalam penelitain. Karena tanpa adaya identifikasi tema-tema, proses deskripsi masalah akan menjadi sia-sia. Tahapan ini dilakukan untuk menemukan informasi yang berkaitan dengan masalah yang akan diteliti oleh peneliti dalam penelitiannya.

3. Mengembangkan neotic/neeomatic correlates

Pengembangkan noetic/neeomatic correlates merupakan tahap ketiga dalam penelitian ini. Noetic yaitu pengembangan pikiran dan intuisi dalam hubungannya dengan intelektual Illahi. Dengan kata lain, dalam penelitian ini peneliti akan mengembangkan tema-tema yang telah diidentifikasi kemudian menghubungkan dengan intelektual ilahi yaitu perspektif agama Islam.

4. Abstraksi intisari atau universals dari neotic/neeomatic correlates

Tahap terakhir dalam penelitian fenomenologi ini yakni membuat abstraksi. Abstraksi merupakan gambaran singkat mengenai intisari dari noetic/neeomatic correlates. Abstraksi ini berfungsi untuk menjelaskan isi secara singkat kepada pembaca, sehingga dari abstraksi yang dibuat pembaca dapat mengerti inti penelitian ini. Tujuan dari penelitian ini adalah untuk mengetahui bagaimana persepsi informan dalam menanggapi kasus pelanggaran etika profesi oleh Akuntan

Publik yang menyebabkan problematika dengan ditinjau dari perspektif agama Islam.

\section{Hasil Penelitian Dan Interpretasi}

\subsection{Deskripsi Data Penelitian}

Data yang diperoleh dalam penelitian ini merupakan data primer karena data dikumpulkan melalui wawancara langsung dengan informan. Wawancara dilakukan secara mendalam dengan membuat pertanyaan kunci yang akan dijawab oleh informan. Wawancara informan dengan latar belakang akuntan publik yang sekaligus sebagai akuntan pendidik dilakukan di Fakultas Ekonomi dan Bisnis Universitas Bhayangkara Surabaya. Informan dengan latar belakang akuntan publik yang sekaligus sebagai akuntan pendidik ini yaitu Bapak M. Latar belakang pendidikan informan yaitu sarjana dan magister akuntansi, beliau juga menempuh pendidikan profesi akuntansi untuk gelar Ak.CA. Sedangkan, wawancara informan kedua dengan latar belakang seorang ulama' yaitu Bapak DB sebagai dosen agama Islam dan Kemuhammadiyahan, beliau juga aktif di majelis tarjih dan Dewan Syariah Nasional perwakilan Jawa Timur.

Hasil wawancara mencakup persepsi akuntan publik dan ulama' terhadap banyaknya kasus pelanggaran etika akuntan publik di era kompetitif seperti sekarang ini, faktor pelanggaran etika akuntan publik, serta dampak yang ditimbulkan dari pelanggaran tersebut. Setelah itu peneliti mengarahkan informan untuk meninjau bagaimana pelanggaran etika 
akuntan publik dari perpektif etika Islam. Pernyataan dari informan kemudian dikaji menggunakan unit analisis sikap yang bersumber pada teori dan penelitian terdahulu. Sehingga hasil penelitian dapat menjawab rumusan masalah dan memberikan kesimpulan dalam penelitian ini.

\subsection{Analisis Data dan Interpretasi Hasil}

4.2.1. Persepsi Akuntan dan Ulama' Terhadap Problematika Etika Profesi Akuntan Publik

Di era kompetitif seperti sekarang ini, profesi akuntan publik semakin menghadapi tantangan yang begitu berat. Terutama dalam hal mempertahankan kepercayaan publik. Sudah tidak menjadi rahasia lagi begitu banyak problematika pada profesi akuntan publik salah satunya yaitu banyaknya pelanggaran etika profesi diluar negeri tidak terkecuali di Indonesia, yang melibatkan kantor akuntan publik maupun akuntan publik sendiri. Salah satu contoh kasus pelanggaran etika profesi akuntan publik adalah yang terjadi dalam kasus PT. Great River Tbk. Dimana BAPEPAM menemukan indikasi penggelembungan account penjualan, piutang dan aset hingga ratusan milyar yang mengakibatkan perusahaan kesulitan likuiditas. Seperti apa yang diungkapkan Informan M terkait kasus tersebut:

"Ya berarti kantor akuntannya tidak professional. Professional kok seperti itu. Kita harus bersikap professional dan independen. Kalau memang seperti itu kita tahu kan ada klien kita menyalahgunakan seperti itu, ya kita harus teliti dan jeli, kan akuntan itu harus menggunakan keahliannya. Kalau dia melaksanakan pekerjaannya itu sesuai dengan tingkat keahliannya, saya kira kejadian seperti itu bisa diperkecil."

Menurut persepsi informan atas kasus di atas bahwa pelanggaran etika profesi akuntan publik dapat di minimalisir dengan cara pemahaman dan penerapan kode etik oleh akuntan publik salah satunya dengan memiliki sikap kompetensi, independensi dan profesionalisme yang memadai. Dalam (Pravitasari, 2015) kode etik perlu diterapkan pada profesi akuntan untuk menghindari perilaku tidak etis ketika seorang akuntan menjalankan tugasnya dan untuk menghindari pelanggaran etika. Selain itu, dilema etika merupakan faktor dasar yang dapat menyebabkan pelanggaran etika profesi akuntan publik terjadi. Dilema etika terjadi ketika akuntan publik dihadapkan antara mementingkan kepentingan publik atau kepentingan pribadi. Contohnya seperti akuntan publik diminta untuk tetap independen dari klien, tetapi pada saat yang sama kebutuhan mereka tergantung pada klien karena fee yang diterimanya sehingga menimbulkan rasa kekhawatiran berlebihan apabila kehilangan klien akhirnya melakukan segala cara untuk dapat mempertahankan klien sekalipun harus melakukan pelanggaran etika profesi. Seperti apa yang dikatakan bapak M sebagai berikut :

"Kalau menurut saya ya faktor tentunya begini. Kan ada pendapat yang bilang kalau banyak kantor akuntan publik yang hanya jual stampel, dan hanya inginkan klien saja. Dan misalnya kalau terlalu ketat, nanti takutnya klien saya akan hilang."

Dilema karena takut kehilangan klien yang akan berdampak pada minimnya pendapatan adalah godaan bagi akuntan publik untuk tetap independent menjaga etika profesinya. Faktor ekonomi tersebut dapat membuat akuntan publik mempertaruhkan apapun tidak terkecuali melanggar etika dalam profesinya dengan cara menuruti apapun yang klien inginkan seperti memberikan opini audit yang tidak berdasar pada kebenaran. Selain faktor ekonomi, faktor kepentingan pribadi yang ditunjukkan dengan mengingankan hal yang lebih dari apa yang sekarang dimiliki termasuk juga menginginkan reward, dapat menjadi dorongan seseorang tidak terkecuali akuntan publik untuk melakukan pelanggaran etika profesinya. Seperti apa yang dikatakan bapak DB, sebagai berikut :

"Titik itulah yang akhirnya menyebabkan orang-orang kadang ada yang mereka berbeda, yang satu melakukan pelanggaran karena ada imingiming tertentu. Mungkin ada satu hadiah atau reward yang besar." 
Hal tersebut menunjukkan bahwa faktor ekonomi dan kepentingan pribadi merupakan godaan yang besar dalam profesi akuntan publik yang dapat mendorong akuntan publik melakukan pelanggaran etika profesinya. Menurut (Sitohang, 2016) bahwa godaan yang besar dalam profesi akuntan publik merupakan salah satu penyebab kegagalan menerapkan etika profesi. Godaan tersebut datang dari dua kepentingan, yaitu kepentingan korporasi dan kepentingan pribadi. Di satu sisi, pekerjaan akuntan publik mempunyai akibat terhadap eksistensi perusahaan atau lembaga di mata publik. Di lain sisi, akuntan publik berhadapan dengan berbagai ancaman yang muncul dari diri sendiri seperti ancaman kepentingan pribadi maupun ancaman dari luar seperti intimidasi dan kepentingan keluarga. Seperti yang dikatakan bapak M, sebagai berikut :

"Sanksi berat yaitu dicabut izinnya, sanksi pidana jarang terjadi. Seberat-beratnya biasanya tidak sampai dipidanakan, jarang saya dengar. Teguran misalnya, tidak boleh mengaudit ini dalam waktu sekian. Sanksi terberat ya dicabut izinnya itu, kalau sudah itu kan ya sudah selesai".

Pencabutan profesi atau pencabutan izin praktik merupakan dampak yang harus ditanggung oleh akuntan publik ketika melakukan pelanggaran etika pada profesinya. Dengan adanya pencabutan profesi atau pencabutan izin praktik tersebut juga akan berimbas pada nama baik profesi akuntan publik dan bagi akuntan publik atau kantor akuntan publik yang lain. Hal tersebut juga seperti diungkapkan bapak M, sebagai berikut : "Kejadian-kejadian seperti itu akan membawa dampak ke nama baik profesi. Padahal, ulah dari satu atau kantor akuntan tertentu saja. Yang lainnya ikut kena imbasnya".

Hal tersebut mencerminkan bahwa dampak paling fatal dari pelanggaran etika profesi akuntan publik adalah hilangnya nama baik profesi akuntan publik, tidak terkecuali akuntan publik yang tidak melakukan tindakan pelanggaran tersebut sehingga mengakibatkan menurunnya kepercayaan publik terhadap profesi akuntan publik. Padahal kepercayaan publik sangat penting agar jasa profesi akuntan publik ini terus diharapkan publik, sehingga profesi akuntan publik akan tetap hidup. Penegakan dan pelaksanaan etika profesi secara tepat oleh akuntan publik tentu diperlukan agar kasus pelanggaran etika profesi dapat diminimalisir, sehingga publik akan terus mengharapkan jasa dari profesi akuntan publik. Seperti apa yang dikatakan bapak M seorang akuntan publik, sebagai berikut :

"Profesi ini supaya bisa dipercaya ya jaga etika profesi itu. Itu menurut saya. Profesi ini kan tempat kita mencari nafkah. Nah kalau mau profesi ini dihargai orang lain ya pertahankan profesi ini jalankan kode etik profesi, supaya profesi ini dapat dipercaya. Kalau sudah profesi ini dipercaya, orang sudah tidak mencibir lagi. Selama ini kan banyak yang mencibir, halah akuntan itu jual stampel. Nah kalau sudah seperti itu siapa yang memanfaatkan jasa profesi akuntan publik. Secara pribadi, tentunya anda sendiri untuk kita sudah dipercaya orang lain itu mencari rezeki itukan mudah. Tapi kalau semua anggota profesi itu tidak dipercaya, profesi itu hancur dengan sendirinya".

Menurut informan, kepercayaan publik dapat dibangun dengan cara selalu memegang teguh etika profesi dan menjalankannya dengan baik. Seperti pendapat dari (Hasan, 2009) bahwa diperlukan penegakan etika bagi akuntan publik, agar mampu menghilangkan krisis kepercayaan masyarakat terhadap akuntan publik.

Dengan demikian dapat disimpulkan berdasarkan hasil wawancara dan analisis pernyataan jawaban informan dari penelitian ini bahwa pelanggaran etika profesi akuntan publik terjadi ketika akuntan publik tidak menerapkan dan memahami etika profesinya secara tepat. Faktor utama yang menyebabkan akuntan publik tidak menerapkan dan memahami etika profesinya secara memadai adalah karena adanya faktor ekonomi dan faktor kepentingan pribadi.

4.2.2.Persepsi Akuntan dan Ulama' Terhadap Problematika Etika Profesi Akuntan Publik dalam Perspektif Islam 
Islam merupakan agama yang universal, yang mana Islam tidak hanya mengatur bagaimana hubungan manusia dengan Tuhannya, hubungan manusia dengan manusia, dan manusia dengan alam di sekitarnya. Tak hanya mengatur urusan akhirat saja, Islam juga mengatur urusan dunia termasuk segala permasalahan yang ada di dunia telah diungkapkan dalam $\mathrm{Al}$ Qur'an. Pelanggaran etika profesi akuntan publik merupakan tindakan yang tidak sesuai dengan ajaran Islam karena jelas hal tersebut merupakan tindakan yang hanya mementingkan kesenangan duniawi dan kepentingan diri sendiri saja yang juga berdampak merugikan banyak pihak. Tindakan yang hanya menguntungkan diri sendiri dan merugikan orang lain tentu itu merupakan hal yang tidak mencerminkan ajaran Islam, karena dapat dikatakan gharar. Seperti apa yang dikatakan Bapak DB, sebagai berikut :

"Ketika kita mencari rezeki ya cari yang halal, tidak haram, tidak subhat, tidak gharar. Gharar itu transaksi yang tidak jelas. Barang yang tidak baik, dianggap baik. Ya paling tidak, dia kadang-kadang mencari keuntungan hanya untuk diri sendiri bukan untuk orang lain. Ini

Gharar".

Hal tersebut menjelaskan bahwa tindakan yang hanya berlandasan mencari keuntungan pribadi dan merugikan orang lain termasuk hal yang tidak dianjurkan Allah dalam etika profesi sesuai Islam. Sedangkan menurut perspektif Islam, profesi akuntan dan auditor merupakan profesi yang diperlukan sebagai fardhu kifayah. Artinya seorang akuntan dan auditor muslim dituntut untuk menjalani profesinya dengan akhlak yang baik. Salah satu tujuan dari hal tersebut adalah untuk meyakinkan keakuratan dan keandalan laporan keuangan, sehingga dapat meningkatkan kredibilitas dan kepercayaan kepada jasa yang diberikan akuntan ataupun auditor (Gustani (2012) dalam (Kusumaningtyas, 2016)). Hal tersebut menegaskan bahwa tindakan pelanggaran etika profesi oleh akuntan publik jelas bukanlah hal yang diperbolehkan oleh Islam, karena di lakukukan berdasar akhlak yang tidak baik. Islam mengajarkan umatnya untuk selalu mencari kebaikan dan menghindari keburukan. Seperti apa yang diungkapkan oleh Bapak M, sebagai berikut :

"Agama Islam itu amal makruf nahi mungkar yaitu berlomba-lomba dalam kebaikan dan mencegah keburukan."

Pelanggaran etika profesi tentunya merupakan tindakan yang tidak beretika dan itu bukan merupakan tindakan yang mencerminkan Islam karena berdampak pada kerugian banyak pihak terutama pemangku kepentingan atas keputusan opini akuntan publik tersebut. Allah menegaskan kepada hamba-Nya dalam surat Al-Baqoroh ayat 148 untuk berlomba-lomba dalam kebaikan :

"Dan bagi tiap-tiap umat ada kiblatnya (sendiri) yang ia menghadap kepadanya. Maka berlomba-lombalah kamu (dalam berbuat) kebaikan. Di mana saja kamu berada pasti Allah akan mengumpulkan kamu sekalian (pada hari kiamat). Sesungguhnya Allah Maha Kuasa atas segala sesuatu”.

Sebagai umat Islam, hendaknya kita mengikuti apa yang diperintahkan Allah SWT dan menjauhi apa yang menjadi larang-Nya. Tindakan pelanggaran etika profesi merupakan salah satu tindakan yang tentunya dianggap tidak beretika sesuai dengan perspektif Islam karena dalam hal ini akuntan publik mendapatkan imbal balik dari klien atas apa yang seharusnya tidak didapatkannya dengan cara yang tidak baik. Allah memerintahkan untuk mencari rejeki dengan cara yang baik, seperti yang dikatakan Allah dalam surat Al-Baqarah ayat 267-268, yang artinya :

"Hai orang-orang yang beriman, nafkahkanlah (dijalan Allah) sebagian dari hasil usahamu yang baik-baik dan sebagian dari apa yang Kami keluarkan dari bumi untuk kamu. Dan janganlah kamu memilih yang buruk-buruk lalu kamu menafkahkan daripadanya, padahal 
kamu sendiri tidak mau mengambilnya melainkan dengan memicingkan mata terhadapnya. Dan ketahuilah, bahwa Allah Maha Kaya lagi Maha Terpuji. Syaitan menjanjikan (menakutnakuti) kamu dengan kemiskinan dan menyuruh kamu berbuat kejahatan (kikir), sedang Allah menjadikan untukmu ampunan daripada-Nya dan karunia. Dan Allah Maha Luas (karuniaNya) lagi Maha Mengetahui”.

Penyajian opini yang tepat oleh Akuntan Publik atas laporan keuangan bertujuan untuk memberikan informasi atas kondisi keuangan pada pihak yang berkepentingan seperti investor dan terutama kreditur. Apabila opini atas laporan keuangan tidak disajikan sesuai dengan kondisi yang sebenarnya, maka bisa menyesatkan bahkan akan berpengaruh terhadap pengambilan keputusan yang tidak tepat oleh pihak yang berkepentingan atas laporan keuangan tersebut. Tentu banyak dampak negatif yang disebabkan karena ketidakjujuran akuntan publik dalam hal penyajian opini atas laporan keuangan. Islam mengajarkan manusia untuk mencari pekerjaan yang halal dan bermanfaat. Seperti apa yang dikatakan bapak DB mengatakan sebagai berikut :

"Sebagai seorang muslim kita harus betul-betul punya prinsip-prinsip, yang pertama harus melakukan sesuatu khususnya dalam pekerjaan yang halal. Kemudian tahu betul mana yang dilarang dan yang haram, dan yang subhat."

Pelanggaran etika profesi akuntan publik yang dilakukan dengan cara penyajian opini yang tidak benar merupakan tindakan untuk memenuhi kepentingan pribadi, dan jelas dalam hal ini akuntan publik tidak mencari harta dengan cara yang halal dari pekerjaannya. Allah dalam AlQur'an surat Al- Baqarah : 168 secara jelas memerintahkan hambaNya untuk mencari harta yang berkah dan halal, yang artinya sebagai berikut :

"Hai sekalian manusia, makanlah yang halal lagi baik dari apa yang terdapat di bumi, dan janganlah kamu mengikuti langkah-langkah syaitan; karena sesungguhnya syaitan itu adalah musuh yang nyata bagimu”.

(Pulungan, 2014) mengatakan bahwa implementasi dari bekerja perlu dilandasi dan diikat oleh akhlak atau etika atau dalam kata lain landasan etika profesi. Dalam Islam, terdapat empat etika yang harus dimiliki seseorang dalam bekerja, yaitu jujur, amanah, murah hati dan selalu mengingat Allah. Sikap selalu mengingat Allah dan mengharap ridhonya, adalah paling penting dan utama. Dalam bekerja, akuntan publik juga harus selalu menyertakan Tuhan dalam setiap pekerjaannya. Sehingga, ketika akan melakukan tindakan yang tidak baik seperti melakukan pelanggaran etika pada profesinya dapat diurungkan niat tersebut. Seperti apa yang dikatakan bapak M sebagai seorang Akuntan publik, sebagai

berikut :

“ Islam, dalam rukun iman. Secara garis besar itu kan sudah mencakup secara keseluruhan tindakan-tindakan itu. Billahi, percaya kepada ilahi. Percaya kepada gusti Allah, bahwa segala tindakannya itu selalu diawasi. Ada dzat yang lebih tinggi lagi dialam jagat ini yang mengawasi kita. Jadi, kalau kita merasa sudah seperti itu kita mau melakukan apapun itu merasa sudah ada yang mengawasi."

Apabila dalam diri Akuntan Publik telah tertanam keimanan yang kuat, maka niat untuk melakukan pelanggaran etika dalam profesinya tidak akan terjadi. Karena dia percaya bahwa segala tindakan dan perbuatan yang dilakukan didunia ini, pasti ada Allah yang mengawasi. Islam mengajarkan setiap individu untuk selalu memiliki keyakinan bahwa Allah Yang Maha Mengetahui dan Maha Mengawasi pada setiap apa yang hambaNya kerjakan. Seperti apa yang dikatakan Allah dalam Surat Al-Hadid Ayat 4, yang artinya sebagai berikut :

“Dialah yang menciptakan langit dan bumi dalam enam masa. Kemudian Dia bersemayam diatas'arsy. Dia mengetahui apa yang masuk ke dalam bumi dan apa yang keluar daripadanya 
dan apa yang turun dari langit dan apa yang naik kepada-Nya dan Dia bersama kamu dimana saja kamu berada. Dan Allah Maha Melihat apa yang kamu kerjakan”.

Serupa dengan apa yang dikatakan informan bahwa iman harus ada pada setiap pribadi yang berprofesi atau berbisnis:

"Ketika kita bekerja misalnya gini, dalam surat Al Shaf ayat 10 kan Allah menunjukkan dengan kalimat "Wahai orang-orang yang beriman, maukah kamu aku tunjukkan suatu perniagaan yang akan menyelamatkanmu dari azab yang pedih?", dalam konteks ini dia perniagaan sebagai seorang pedagang bisa profesi akuntan, profesi dia hakim, atau profesi dia sebagai penegak hukum yang lain, dia guru, dia dosen, kan sama. Maka dalamnya harus mengikat agar betul-betul orientasinya tidak berdampak pada diakhir nanti dapat azab Allah, maka etikanya sebagai seorang yang berprofesi kita betul-betul menjadikan diri kita sebagai seorang yang beriman."

Hal tersebut menunjukkan bahwa iman menjadi landasan yang penting dalam bekerja atau berprofesi. Karena dengan landasan iman yang kuat maka setiap individu tidak terkecuali akuntan publik akan selalu menyertakan Allah dalam setiap pekerjaannya. Iman juga dapat menyelamatkan seseorang dari azab yang pedih. Seperti apa yang dikatakan bapak DB, hal tersebut tentu telah di tulis oleh Allah dalam Al-Qur'an yaitu di surat Al-Shaf ayat 10

Hai orang-orang yang beriman, sukakah kamu aku tunjukkan suatu perniagaan yang dapat menyelamatkanmu dari azab yang pedih?".

Selanjutnya Allah menerangkan lebih lanjut dalam surat Al-Shaf ayat 11:

“(yaitu) kamu beriman kepada Allah dan RasulNya dan berjihad di jalan Allah dengan harta dan jiwamu. Itulah yang lebih baik bagimu, jika kamu mengetahui”.

Selain Iman, prinsip kejujuran juga penting dimiliki seseorang ketika menjalankan profesi, dan jujur juga merupakan etika profesi dalam perspektif Islam. Setiap pribadi dalam menjalankan bisnis atau profesi harus dilandasi kejujuran, tidak terkecuali akuntan publik atau praktisi akuntansi lainnya. Seperti apa yang dikatakan bapak DB, sebagai berikut :

"Nah khusus yang berkaitan dengan akuntansi dalam Al-Qur'an, sebenarnya Allah banyak memberikan warning kepada kita, contoh yang berhubungan dengan harta ini. Dalam surat At-taghabun ayat 15, Allah berfirman “..Sesunggunya harta-hartamu dan anak-anakmu itu adalah cobaan..", sehingga ada orang yang memang resikonya berhubungan dengan masalah finansial atau keuangan baik dia pelaku akuntan publiknya maupun dia bankernya atau dia marketingnya, sebenarnya dia harus mempunyai sikap yang sama, yang mana dia melakukan kejujuran".

Pelanggaran etika profesi akuntan publik dengan cara manipulasi opini audit tentu bukan tindakan yang sesuai etika dalam Islam, karena tindakan tersebut tidak mencerminkan kejujuran dalam hal tidak menuliskan apa yang sebenarnya tercermin dalam laporan keuangan yang diaudit. Dalam Islam Allah dengan jelas menuliskan semua hal yang berkaitan dengan pembukuan yaitu dalam surat Al Baqoroh ayat 79, sebagai berikut :

"Maka kecelakaan yang besarlah bagi orang-orang yang menulis Al Kitab dengan tangan mereka sendiri, lalu dikatakannya; "Ini dari Allah", (dengan maksud) untuk memperoleh keuntungan yang sedikit dengan perbuatan itu. Maka kecelakaan yang besarlah bagi mereka, akibat apa yang ditulis oleh tangan mereka sendiri, dan kecelakaan yang besarlah bagi mereka, akibat apa yang mereka kerjakan."

Dalam ayat tersebut Allah menegaskan bahwa akan celaka bagi orangorang yang melakukan ketidakjujuran dalam hal pembukuan demi untuk mencari keuntungan. Karena sangat pentingnya prinsip kejujuran dalam hal terkait akuntansi, Allah menerangkan secara rinci dalam surat Al-Baqoroh ayat 282, seperti apa yang dikatakan bapak DB: 
"Kemudian yang berikutnya dalam Al-Baqarah ayat 282 ada prinsip kalau dalam ayat ini ketika ada transaksi ada yang tidak terurai buatlah pembukuan dengan cara yang adil, jadi dengan cara yang benar. Jadi kan tidak boleh ada penyimpangan disitu".

Menyampaikan kebenaran sangat penting apalagi dalam urusan bisnis atau pun profesi. Karena sangat pentingnya kejujuran dalam hal mu'amalah Allah memerintahkan untuk mencatat secara benar dan adil ketika bermuamalah tidak secara tunai. Secara rinci, dalam Al-Baqoroh (2) Ayat 282 Allah berfirman sebagai berikut :

"Hai orang-orang yang beriman, apabila kamu bermu'amalah tidak secara tunai untuk waktu yang ditentukan, hendaklah kamu menuliskannya. Dan hendaklah seorang penulis di antara kamu menuliskannya dengan benar".

Dengan demikian dapat disimpulkan dari hasil wawancara dan analisis pernyataan jawaban informan dalam penelitian ini bahwa pelanggaran etika profesi akuntan publik dengan cara manipulasi penyajian opini atas laporan keuangan yang diaudit merupakan tindakan yang tidak mencerminkan etika profesi dalam Islam, karena adanya unsur ketidakjujuran dalam pemberian opini atas laporan keuangan.

\section{Kesimpulan}

Pelanggaran etika profesi oleh Akuntan Publik karena adanya faktor ekonomi dan faktor kepentingan pribadi. Hilangnya kepercayaan publik atas jasa profesi akuntan publik merupakan dampak yang paling fatal atas pelanggaran etika profesi akuntan publik. Dalam perspektif Islam, tindakan pelanggaran etika oleh Akuntan Publik merupakan tindakan yang tidak beretika, karena adanya unsur ketidakjujuran akuntan publik dalam hal penyajian opini atas laporan keuangan. Hal tersebut tidak sesuai apa yang difirmankan Allah dalam Surat AlBaqarah ayat 79 dan Al-Baqoroh ayat 282. Landasan iman juga penting dimiliki oleh Akuntan Publik dalam menjalankan profesinya. Karena sesuai surat Al-Hadid ayat 15 Allah memerintahkan hambaNya memiliki keyakinan bahwa Allah Maha Mengetahui dan Mengawasi setiap tindakan hambaNya. Selain itu, dalam surat As- Shaf ayat 10-11, dijelaskan Allah akan menyelamatkan hambaNya dari azab yang pedih apabila hambaNya beriman dan menjihadkan harta dan jiwa dijalan Allah.

\section{Daftar Pustaka}

Arifiyani, H. A. (2012). Pengaruh Pengendalian Intern, Kepatuhan dan Kompensasi Manajemen Terhadap Perilaku Etis Karyawan ( Studi Kasus PT. Adi Satria Abadi Yogyakarta). Jurnal Nominal, 6.

Aw, S. (2010). Komunikasi Interpersonal. Yogyakarta: Graha Ilmu.

Bertens, K. (2013). Etika, edisi revisi. Yogyakarta: Kanisius.

Centik, A. S. (2011). Etika Bisnis dan Profesi ( Tantangan Membangun Manusia Seutuhnya). Jakarta: Salemba Empat.

Danarjati, D. P., \& Ekawati, A. (2013). Pengatar Psikologi Umum. Yogyakarta: Graha Ilmu. Gabrillin, A. (2017, Mei Minggu, 28). Kronologi Kasus Dugaan Suap Pejabat Kemendes PDTT dan Auditor BPK. Retrieved Februari Rabu, 21, 2018, from KOMPAS:

http://nasional.kompas.com/read/2017/05/08/02000071/kronologi.kasus.du gaan.suap.pejabat.kemendes.pdtt.dan.auditor.bpk\&hl=id-ID

Harahap, S. (2008). Pentingnya Unsur Etika dalam Profesi Akuntan dan Bagaimana di Indonesia? EKBISI, 2.

Hardiman, F. B. (2016). Filsafat Untuk Para Professional. Jakarta: Kompas. 
Harkaneri. (2013). Urgensi Etika dalam Akuntansi Dilihat dari Sudut Pandang Islam. ELRIYASAH Voume 4 Nomor 1, 49.

Hasan, M. A. (2009). Etika dan Profesional Akuntan Publik. Pekbis Jurnal Volume 1 Nomor 3,159 .

J.Elder, R. (2013). Jasa Audit dan Assurance. Jakarta: Salemba Empat.

Jogiyanto, A. W. (2015). Partial Least Squere (PLS) Alternatif : Structural Equation Modeling (SEM) dalam Penelitian Bisnis, edisi I. Yogyakarta: ANDI.

Koerniawan, K. A. (2013). Etika Profesi dalam Problematika Diera Kompetitif

Menurut Sisi Pandag Akuntan Publik. MODERNISASI Volume 9, Nomor

1, Februari.

Kusumaningtyas, D. (2016). Religiusitas Pada Motivasi dan Etika Profesi Akuntan Dalam Perspektif Islam. Cendikia Akuntansi,Volume 4, Nomor 3, 116-124.

Mahendra, R. (2014, Januari Senin, 20). Kasus WordCom. Retrieved Februari Rabu, 21, 2018, from Blogspot:

http;//rezamahendra09.blogspot.co.id/2014/01/kasus-wordcom.html?m=1

Matondang, Z. (2015). Etika Profesi Akuntansi dalam Perspektif Islam. ALMASHARIF, Volume 3, Nomor 2, 55-67.

Muzakkir, A. (2016, Mei 05). Etika Profesi dalam Islam. Retrieved April 04, 2018, from Wordpress:

http://abdmuzakkir.wordpress.com/2016/05/08/etika-profesi-dalamislam/amp/

Narjono, A. I. (2013). Etika Islam dan Motivasi Kerja (Islam Ethics And Employee Motivation). JIBEKA Volume 7 Nomor 2, 7-13.

Onyebuchi, V. N. (2011). Ethics in Accounting. International Jurnal of Business and Social Science, 275.

Pravitasari, D. (2015). Pemahaman Kode Etik Profesi Akuntan Islam di Indonesia. An-Nisbah, Volume 01, Nomor $02,87$.

Pulungan, S. (2014). Etos Kerja dan Etika Profesi dalam Pandangan Islam. Wahana Inovasi, Volume 3, Nomor 2, 5-6.

Sirajudin. (2013). Interpretasi Pancasila dan Islam Untuk Etika Profesi Akuntan Indonesia. JurnaL Akuntansi Multiparadigma, 456-466.

Sitohang, K. (2016). In Etika Profesi Akuntansi (pp. 82-86). Yogyakarta: PT Kanisius.

Sopanah. (2010). Menguak Fenomena Penolakan Pembangunan dengan Dana Anggran Pendapatan dan Belanja Daerah (APBD) : Sebuah Studi Interpretatif. Simposium Nasional Akuntansi XIII Purwokerto , 13-14.

Sosipater, K. (2012). Etika Pribadi. Jakarta: Suara Harapan Bangsa.

Sugiyono. (2015). Metode Penelitian Kuantitatif, Kualitataif, dan R\&D. Bandung: CV Alfabeta.

Syaharuddin. (2012). Etika Bisnis Dalam Perspektif Hukum Islam (Studi Membagun Sitem Ekonomi yang Humanis). Makassar: Alauddin

University Press.

Tanyid, M. (2014). Etika dalam Pendidikan : Kajian Etis Tentang Krisis Moral Berdampak pada Pendidikan. JAFFRAY, Volume 12, Nomor 2, 237.

Tjun Tjun, L. (2012). Pengaruh Kompetensi dan Independensi Auditor Terhadap Kualitas Audit. Jurnal Akuntansi Volume 4 Nomor 1, 34.

Widyastuti, Y. (2013). Psikologi Sosial. Serang: Graha Ilmu.

Yin, R. K. (2011). Studi Kasus : Desain dan Metode. Jakarta: Rajagrafindo Persada.

Zulganef. (2008). Metode Penelitian Sosial dan Bisnis, Cetakan Pertama. Yogyakarta: Graha Ilmu. 